\title{
SOBRE O DIÁRIO DE NARCISO... AINDA
}

\author{
SIRIO POSSENTI ${ }^{1}$ \\ (UNICAMP)
}

Seria exagero, evidentemente, afirmar que a salvação está na linguística. Mas não é exagero afirmar que é na ciência que reside a possibilidade de que muitas coisas melhorem (mesmo que não se compre ingenuamente a ideia de progresso).

Diante da pobreza dos argumentos recentes sobre o papel do ensino de gramática - concebida da forma mais redutora e desinformada possível - para a "salvação" da escola, esquecendo seu papel crucial para os atuais fracassos, não seria demais afirmar que teses derivadas da linguística do último século poderiam modificar fortemente os rumos atuais. Muitos fatos atestam que esta virada seria possível.

O que vale para a escola vale para outros setores ou para nichos especiais. Tenho em mente as avaliações, os comportamentos e os "tratamentos" decorrentes de uma boa ou de uma equivocada avaliação das afasias e da dislexia, por exemplo, mas também de outros problemas que afetam a linguagem de sujeitos usualmente considerada deficitária.

É de certa forma espantoso que uma sociedade supostamente interessada no bem-estar de todos mantenha desconhecidos determinados pontos de vista, que podem ser equiparados às descobertas que alteram os rumos da pesquisa e fazem avançar a verdade.

Refiro-me ao livro de Maria Irma Hadler-Courdry, Diário de Narciso, derivado de sua tese de doutorado, que celebra 30 anos. Posso dizer que vi nascer o deslocamento que a autora produziu na área. Redigimos juntos um texto anterior à tese. Nesta parceria, meu papel era o de fazer Maria Irma explicitar cada vez mais seus pontos de vista para que eu pudesse compreendê-la. Foi esta convivência que me faz ter certeza de que ela operou um deslocamento no seu espaço de pesquisa e atuação.

\footnotetext{
${ }^{1}$ siriopossenti@gmail.com
} 
Ainda hoje, passados 30 anos, num certo sentido infelizmente, as surpresas que a leitura do livro produz são numerosas (quero dizer que ele deveria ser familiar), considerando o que se lê e ouve sobre dislexia, por exemplo, ou, mais claramente, sobre os critérios a partir dos quais se decide que há um grande percentual de alunos que são disléxicos, especialmente entre os da escola pública (tinha que ser, e é exatamente porque se erra na avaliação dos fatores que produzem o "fracasso escolar"!). Repito: é cruel que este tipo de saber produzido na universidade, não só não sai de seus limites, como nem afeta outros cursos destinados a formar os especialistas que "tratarão" dos cidadãos acometidos de algum "problema" de linguagem. Efeito que se deve claramente ao que há de ideologia na ciência...

Um dos problemas de uma obra como a de Hadler-Coudry (aqui, "obra" não se refere só a este livro, mas ao conjunto dos textos - muitos em co-autoria - e das práticas que dele decorrem) reside no fato de que seu trabalho se situa numa encruzilhada complexa, já que estão envolvidas diversas teorias sobre língua(gem) e sobre cérebro/mente, além de uma diversidade de metodologias de avaliação de linguagem e relativas às práticas mais adequadas para lidar com os sujeitos, sejam alunos, sejam afásicos, entre outros.

Hadler-Coudry anda sempre em uma trilha estreita, e deve operar opções verdadeiramente cirúrgicas, para impedir que ideias parecidas ou práticas esporádicas se confundam com o que veio a ser designado como Neurolinguística Discursiva ou para que ela seja adequadamente incorporada por quem se dê conta de que outras abordagens são insuficientes.

A complexidade aumenta quando se quer avaliar este trabalho nos termos da ciência - ou da verdade, como acima postulei. O tópico dos testes de avaliação (supostamente universais) é um bom "exemplo". Talvez a mais contundente intervenção do Diário tenha sido, no final da década de 1980, relativa ao caráter metalinguístico dos testes. De novo, aqui, a comparação com práticas escolares ajuda a compreender o alcance dessa intervenção. Sabemos que muitas aulas ou provas de "preencher" lacunas são consideradas tanto uma forma ensinar regras gramaticais como de avaliar seu aprendizado. E todos sabemos que são ineficazes tanto como forma de ensino (se fossem eficientes, ninguém mais diria "haviam pessoas" nem "se eu ver") e também como forma de avaliação (seu eventual emprego não transforma ninguém em ignorante nem uma oração em sequência incompreensível).

Um exemplo é suficiente para marcar a insuperável diferença: na página 90 do Diário pode-se ler:

$\mathrm{N}$, nas situações de teste-padrão em que as expressões estão descontextualizadas, mostrava grandes dificuldades em nomear objetos, com escores praticamente nulos; quando, porém, em uma das visitas nos sentamos à mesa para almoçar, $\mathrm{N}$ teve facilidade em apresentar, um a um, os pratos que iríamos comer:

(15) N. - Lazanha, frango, aqui salada, maionese, arroz. Fui eu que escolhi tudo. 
Fatos como este, ou com este tipo de efeito - de desmontar todos os diagnósticos fundados nos testes padrão, que são metalinguísticos - marcam o livro, que, portanto, indica que tudo deve ser revisto, que os dados linguísticos e os sujeitos devem ser considerados a partir de outro ponto de vista. O caso acima lembra acontecimentos escolares do mesmo calibre, com efeitos quase anedóticos, se não fossem por demais severos, como o da criança que reagiu assim, com uma frase perfeita, a uma das tarefas mais características propostas pela nossa escola: "Mas tia, eu não sei fazer uma frase".

Diário de Narciso tem tudo a ver com o que inspirava um grupo de linguistas do Instituto de Estudos da Linguagem, na Unicamp. O programa gerativista era evidentemente forte - e conhecido. Mas outras vozes se faziam ouvir, duas delas originadas de pesquisadores do próprio IEL: Carlos Franchi, com sua tese sobre a atividade constitutiva que a linguagem é, e Cláudia Lemos, com seu projeto de aquisição da linguagem fundado na atividade dialógica. Eram programas revolucionários e em construção, que todos conhecíamos de alguma maneira.

Maria Irma os incorporou, mas tendo em vista seus interesses, em torno da neurolinguística, que também concebia à sua maneira. As teorias da enunciação eram um pano de fundo, não tanto pelos efeitos que produzia em torno das questões da subjetividade, mas pela sua dimensão "pragmática" e dialógica, no sentido benvenisteano.

O trabalho de Maria Irma, nesses 30 anos, sofreu evidentemente revisões. Especialmente, houve outras leituras, outros corpora. E aconteceram o CCA e o CCAzinho, lugares de convivência com os sujeitos, que, entre outras coisas, lhes restituía confiança e formas de vida que lhes davam novas esperanças. Maria Irma nunca manteve com seus sujeitos uma relação de coleta de dados, mas uma relação de certa forma terapêutica, durante a qual não necessariamente "curava" pessoas, mas estabelecia com elas e com suas famílias relações que permitiam que se sentissem bem mesmo sendo diferentes, e, especialmente, desenvolver e valorizar novas e alternativas formas de conversação, para cuja compreensão e desenvolvimento colaborou fundamentalmente a defesa de uma relação contextualizada da linguagem (não baseada nos testes, que denunciam equivocadamente um sujeito incapaz...).

Foi este tipo de interesse pelas pessoas que a levou a outras fontes, a Freud (especialmente sobre escrita), a Foucault (por sua pesquisa sobre a medicina e sobre os diversos dispositivos que regem nossas vidas - e contra os quais ele incita todos a lutar, causa a que Maria Irma aderira mesmo antes de conhecer esta formulação), a Agamben, pelo aprofundamento deste conceito, sem contar Canguilhem, com seu O normal e o patológico, que lhe dá segurança para lutar contra a expectativa torta de que todos devam ser iguais para serem considerados normais.

Poderia parecer que, dado isso, não vale mais a pena retomar Diário de Narciso. Mas vale, porque tudo isso já está lá, de alguma forma, mesmo que não nos mesmos termos. Diário discute os conceitos que surgiam na linguística, operava distinções sutis entre diversas concepções do cérebro e, especialmente na segunda parte, descrevia e justificava uma espécie de prática clínica - ou do que ela deveria ser, se "eles" compreendessem melhor o que são e o que afeta as práticas linguísticas reais. 
Pode-se dizer, então, que Maria Irma descobriu tais questões independentemente, e que esses autores (e outros) estavam a sua espera, para que ela os lesse e incorporasse novos aspectos a sua compreensão dos fatos que a afetam, e também para que os que trabalharam e trabalham com ela possam sentir-se mais bem servidos de teoria, já que nem todos são capazes de dar conta sozinhos, como Maria Irma, de tantas questões. 